Hill, David ORCID: https://orcid.org/00000002-3849-1170 (2013) Avatar Ethics: Beyond Images and Signs. Journal for Cultural Research, 17 (1). pp. 69-84.

Downloaded from: http://ray.yorksj.ac.uk/id/eprint/3950/

The version presented here may differ from the published version or version of record. If you intend to cite from the work you are advised to consult the publisher's version: https://www.tandfonline.com/doi/full/10.1080/14797585.2012.719689

Research at York St John (RaY) is an institutional repository. It supports the principles of open access by making the research outputs of the University available in digital form. Copyright of the items stored in RaY reside with the authors and/or other copyright owners. Users may access full text items free of charge, and may download a copy for private study or non-commercial research. For further reuse terms, see licence terms governing individual outputs. Institutional Repository Policy Statement

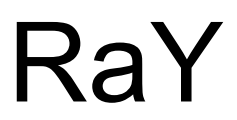

Research at the University of York St John

For more information please contact RaY at ray@yorksj.ac.uk 
Title: Avatar Ethics: Beyond Images and Signs

Author Information: Dr David W. Hill, Department of Sociology, University of York

Address: Department of Sociology, Wentworth College, University of York, Heslington, York, YO10 5DD

Telephone: 01904324735

Email: dwhill14@gmail.com

Biographical Note: David is based in the Department of Sociology, University of York. He received his doctorate from York in March 2012 for a thesis on ethics and new media. His research interests include: post-structuralism; everyday life and public space; and the sociology of ethics and morality. 
Abstract: Emmanuel Levinas argues that moral responsibility is enacted in the encounter between two people. Increasingly, however, encounters take place online and, rather than between two people, are mediated by virtual representatives known as avatars. In this paper I explore the theoretical conditions for grounding encounters between users mediated by these online proxies, and the extent that they can be convincingly cast as moral. First, I draw on aesthetic theory in order to argue that online environments in which such interactions occur can gesture towards the moral responsibilities experienced in the offline world. Second, I explore ways of grounding the encounter in these online environments through theories of signification, ultimately utilising Jean-François Lyotard's notion of the tensor read alongside the Levinasian ethical demand. Altogether, this paper attempts to provide an articulation of the very possibility of responsibility enacted and mediated through avatars and, as such, focuses upon the basic conditions of moral life online in order to provide a theoretical grounding.

Key words: Avatars - Ethics - Levinas - Lyotard - Images - Signs 


\section{Avatar Ethics: Beyond Images and Signs}

Since Neal Stephenson used the term in his cyberpunk novel Snow Crash (2002), originally published in 1992, "avatar" has become widely employed to define the sign through which we socialise online. Mathias Klang writes: "The online character is often seen as a reflection of the offline self and is in literature referred to as the avatar since it is a manifestation of the self in this online world" (2004, p. 390). ("Avatar" comes from the Sanskrit meaning manifestation of God.) Stephen Webb offered an early analysis of the avatar used in a now defunct chat site, with the avatars in question being photographs, cartoons, or animations of users. For David J. Gunkel (2010, p. 128) an avatar is simply a representation of the user that can be interacted with by other users; this is a definition so broad that it could conceivably include any form of identification online, from the profiles and photographs that make up a large part of social networking to an animated rendering of the user in a graphical world. For L. D. Falvey (2011, p. 56) it is one of the "real life' signs" employed by users in order to participate in social behaviours. What all these accounts - and many more - have in common is that they conceive of the avatar as a social entity utilised in social environments; it can be still or animated, photographic or graphic; and it stands in for the user as a proxy. It is through avatars that we socialise online, maintaining friendships, conversations, or shared interests (such as playing games or sharing hobbies).

However, the idea that encounters between users can take place through these proxies is not unproblematic. Slavoj Žižek argues that, by dint of online design, we need a representation of ourselves for virtual interaction (an avatar) but it is one that can never fully represent us: "The other is thus purely virtual: no longer a true, living, intersubjective other, but an inanimate screen, a stand-in" (1999, p. 107). This is, according to Žižek, too passive to constitute an 
encounter. We never really encounter the other, just the manipulated and fabricated signals sent through a computer (Žižek 1999, p. 108). The nature of the interface - between avatars, via a computer or mobile device screen - "means that my relationship to the Other is never face-toface" (Žižek 1999, p. 113). If the avatar is merely an "interface simulacrum” (Žižek 1999, p. 109) and the face-to-face impossible online, then what I want to argue first is that it poses a problem for the application of the ethical encounter, as found in the work of Emmanuel Levinas. I will then argue that we can begin to rehabilitate Levinasian ethics online if we reject his stance that images are not morally provoking by turning to the aesthetic theory of Aristotle (and Hans-Georg Gadamer's return to this classic account) and Immanuel Kant. This will allow us to conceive of online environments as moral spaces. Finally, I will argue that avatars as extensions of the self allow for an ethical encounter to occur between two users. This demands a return to theories of signification and I will conclude by appropriating from Jean-François Lyotard the notion of the tensor, a kind of sign that allows for a visceral meeting of bodies, but emphasising a moral dimension lacking in Lyotard's radical account of signification by reading it alongside Levinas' moral philosophy. This will give us a theoretical underpinning for the idea that encounters take place online and that these encounters are sufficient to ground moral responsibility without physical proximity. It should be noted at this point that this is very much a groundwork rather than a sustained engagement with moral problems encountered though avatar interaction (cyberbullying, deception, etc.); the focus is the sine qua non of moral life online and so it is beyond the scope of this paper to move beyond the theoretical conditions and towards substantive ethical issues.

\section{Levinas}


It is in the face-to-face - thrown into doubt online by Žižek - that Levinas grounds responsibility, this notion of responsibility constituting being-towards (or being-for) another person. For Levinas (2007), the face-to-face encounter with the other person ("other") puts the individual (the "I") in a relation with infinity. In simple terms, the "I" is confronted by something (the other) which escapes her ability to fully comprehend, meaning that it cannot be totalised in thought - there is always something that cannot be known, infinity (see Caygill 2006). Levinas writes: "The way in which the other presents himself, exceeding the idea of the other in me, we here name face" $(2007$, p. 50$)$. That is to say that it is the face of the other that expresses this infinite dimension, the face of the other that makes the "I" aware that what is before her is something beyond her control - something that resists her. What this expression of infinity - of complete otherness - conveys, then, is that before the "I" is another being whose motives and desires remain opaque and so towards whom "I" should act in a way that does not do violence to those hidden intentions. Levinas calls this the "calling into question of my spontaneity", that is, the imposition of limitations on one's own freedom or, simply, "ethics" (2007, p. 43).

Whilst on one level this encounter with the other leads the "I" to act with a sense of responsibility as to how those actions impact upon the other, on another level responsibility becomes more active - it becomes response. The face is always expressive of the need for responsibility towards the other but when it becomes expressive of suffering it becomes a call to the "I" to respond in some way to expiate this suffering, to take responsibility for the alleviation of that suffering. The suffering expressed by the face of the other "imposes on me and I cannot stay deaf to its appeal, or forget it, [...] I cannot stop being responsible for [the other's] desolation" (Levinas 2006a, p. 32). For Levinas, the mute expression of the face is fundamentally moving but he also sees the dialogic call for help as being a profound ethical 
event, where speech acts as a kind of moral signification that demands a response. In both cases this response is immediate, in the sense that it occurs in the moment and without reflection; Levinas' is an anti-foundational ethics in that it does not operate on moral prescriptions - or even judgement. First, any sort of moral guidance would be general - pertaining to the same rather than suitable for the specific other who is in need; and second, given the fundamental aloofness of the other, we can never know that the way we respond is correct or possess any knowledge from which to judge the right course of action. So the encounter with the other arouses the goodness of the "I" in the moment and response must be immediate, both temporally and in the sense of without recourse to moral mediation or advice. This kind of response is the "gesture" of ethics (Levinas 2007, p. 174).

Whilst Julia Hell (2010, p. 145) has noted, and Zygmunt Bauman (in Dawes 2011, p. 131) has confirmed, that there is a connection, in Levinas, between looking at the other and being moved to respond to the other, Levinas himself saw limitations to this specular dimension of ethics. Across both his Totality and Infinity (2007) and Otherwise Than Being (2008b) Levinas argues that the face of the other - so vital for ethical encounters - cannot be represented as an image. The face is the focal point of the expression of otherness but for something to be represented is for it to be made intelligible - and what is made intelligible no longer remains as other. Levinas calls this the "imperialism of the same" (2007, p. 59), a totalising process. Since Levinas' ethics is based on the encounter with the other as other, anything that would translate this otherness into an intelligible same cannot be part of the moral realm. This, for Levinas, includes images of the other, which is potentially problematic when we consider encounters online. 
This abstract philosophical argument about otherness and image is supplemented by Levinas with some more grounded observations in his essay "Reality and its Shadow" (2006b). Levinas' focus in this piece is on art and literature but the conclusions he draws here are, I suggest, responsible for the tout court dismissal of the value of images in his two major works of ethics. He writes: "The most elementary procedure of art consists in substituting for the object its image"; in turn, the image "neutralizes" the object (Levinas 2006b, p. 3). Any object turned into an image becomes a non-object, a sensation. It resembles the object, like a shadow or an "allegory of being" (Levinas 2006b, p. 6). In an artwork, says Levinas, the presence of that which resembles the object - the spots of colour or slabs of marble - only serve to point to the absence of the object. For Levinas, the image of the other is a sign that the other is not there, that there can be no encounter with this absent other. Whereas the face of the other presents only itself to the "I" in the encounter, opening up a moral relationship, the image of the other is a representation, a shadow, an allegory - a non-other.

Additionally, for Levinas, there is something troubling about this image of the (absent) other. He writes: "every image is in the last analysis plastic, and [...] every artwork is in the end a statue - a stoppage of time, or rather its delay behind itself" (Levinas 2006b, p. 8). In the statuesque image, "an instant endures infinitely"; for example, "the Mona Lisa will smile eternally" but it is a smile that never broadens (Levinas 2006b, p. 9). In this suspended instant nothing can ever happen. This has two effects: first, the "I" cannot respond immediately to the image of the other because such a response has a temporal dimension which is here frozen; and second, the statuesque image of the other is incapable of expression (Robbins 1999, p. 84). Like the Mona Lisa's smile, the expression of the face will never fully form and likewise the words to which the "I" would respond are stuck in a mouth that cannot speak. There is nothing for the "I" to respond to; the image has no ethical function because it is inexpressive and mute. 
These, then, are the three arguments that Levinas puts forward to dismiss images of the other from the moral sphere: first, they translate otherness into the same; second, their presence highlights only the absence of the other; and, finally, their frozen quality makes response impossible. Immediately the last of these arguments appears untenable if applied to the avatar, which returns expression to the image. The animated avatar used in graphical worlds is not frozen and, although expressions cannot be as subtle as they are offline, the use of text-based chat or speech through a microphone returns what Jill Robbins calls the "language-response to the other" (1999, p. 54; see also Boothroyd 2005 for an account of language as hospitality towards the other). The profile avatars used in social networking do indeed contain frozen images but they also allow for language-response through text conversation which, since the image is the focal point and not the entirety, is indissociable from the avatar. The other two arguments require more sustained critical reflection, since the first would cast virtual environments as an amoral shadow world whilst the second would suggest that the avatar is incapable of signifying the other person it is intended to stand in for. To overcome the former we need to rethink how images relate to otherness, which is the work of the next section; and for the latter, we need to ground the encounter between two users such that avatars are not mere interface simulacra, which is addressed in the final section.

\section{Image}

In what follows I will first utilise the aesthetic theory of Aristotle and Hans-Georg Gadamer to argue that, whilst the other may not be encountered herself, images can gesture towards responsibilities; and, second, through Immanuel Kant's analytic of the sublime, I will argue 
that the unintelligible - otherness - can be gestured towards by the image. Taken together, it will then be possible to argue that images of others online gesture towards the responsibility we are confronted with in the encounter with the other. Whilst this is not sufficient to hold that encounters between users take place, it will allow us to conceive of graphically- and photographically-rendered environments as sites in which responsibility is cultivated.

\subsection{Imitation and Gesture}

Aristotle's famous work on the aesthetic in his Poetics (1997) was written in response to Plato's dismissive account of art as imitation in his Republic (1997). Plato's argument was that art was doubly inferior, since it was an imitation of something that was an imitation (the sensible world) of the real thing (the forms). Aristotle took this notion of imitation and explored what value it might have to those who contemplate art (drama in particular). He argued that it is through imitation that we learn - as children learn through imitation play - and so through the imitation of something in art we learn about the thing that is imitated. Aristotle writes that "the reason why men enjoy seeing a likeness is, that in contemplating it they find themselves learning or inferring, and saying perhaps, 'Ah, that is he"” (1997, p. 6). This last part - the "Ah, that is he" - is both vital to our present study of avatars and a little misleading. For it is not the person depicted that we learn about but of the actions and character of people. At the same time, not all art has an ethical function which is to say, for Aristotle, that it is not all educative of character. In those dramas (or paintings, as we will see presently through the work of Gadamer) that do have an ethical function, regardless of their trueness to life or not, lessons are learned about moral decisions: "Character is that which reveals moral purpose, showing what kind of things a man chooses or avoids" (Aristotle 1997, p. 13). Whilst works of art that exaggerate moral character are obviously fictive, the function they play is not so much in 
depicting things as they are or as they are perceived to be but how they ought to be (Aristotle 1997, p. 53). So, contemplation of a drama or a painting that depicts moral heroism or failing educates about what ought to be done whilst scenes of suffering arouse pity; in short, art can be ethical and our experience of things imitated is no less powerful than of things themselves when it comes to moral education.

Whilst the work of Aristotle shows that art was regarded as possessing an ethical quality early in the Western philosophical tradition, it is Gadamer's reassessment of this work that begins to challenge Levinas' dismissal of images. Gadamer (1986c) indirectly approaches Levinas' concern for "the speechless image" by arguing that, although the image of a person is incapable of speech, there is nevertheless a kind of language: a gesture. Returning to the Aristotelean account of imitation, Gadamer (1986a, p. 99) argues that mimesis makes something present, allowing us to recognise something we have already encountered. It is through art, then, that our familiarity with the world is deepened; art is a way of maintaining familiarity with a world that is "dissolving" all around us (Gadamer 1986a, pp. 100-104). However, art is not a depiction of an actual event but a "gesture" that presents the being of the event (Gadamer 1986b, p. 79). For example - Gadamer's (1986b, p. 81) example - Werner Scholz's painting Antigone is not a depiction of the person named Antigone but a gesture representing self-chosen death. Symbolic gestures are embedded in the canvas; even when they represent humans the gesture remains just the art work - but gesturing towards human reality, towards the inner life of human subjectivity. This is only ever a gesture since if the artist could express this in a more robust manner - codify it, say - then they would not need to create the art work. "The images before us present human life in the language of heraldic emblems and devices" (Gadamer 1986b, p. 81), and through them we encounter the unfamiliar. Reflecting on modern art, Gadamer writes: "Even the art of our own time, whose mute gaze presents us with such disturbing enigmas, 
remains a kind of recognition: in such art we encounter the undecipherability of our surroundings" (Gadamer 1986b, p. 74).

We are now in a position to challenge Levinas' contention that images are not ethical in nature. What Aristotle and Gadamer demonstrate is that images teach us about moral responsibility. Not all images, obviously, but where, say, human suffering is depicted in a photograph or graphical representation it renews in the instant of viewing the idea within us that the suffering of others is unacceptable. Of course, Levinas' antifoundational ethics has no place for indoctrination of values or the learning of moral lessons: ethics is an immediate response to the other. But what Aristotle and Gadamer are arguing is not that we can read off prescriptions but rather that we gain a familiarity with the moral world - in the same way that we would through face-to-face encounters in Levinas' account. Gadamer's observation, that our familiarity with a world dissolving around us is maintained through art, is particularly interesting in this respect. Bauman, in his Modernity and the Holocaust (2007), warned of the disappearance of Levinas' other through bureaucracy and technology, and what we cannot be aware of we cannot be responsible for. Today, when technological interaction takes place with physically absent others, it is through images - amongst other things - that we maintain a grip on the reality of the world, suffering and all. Some images - not all, as Aristotle noted - gesture towards how we ought to behave towards people. Levinas is too hasty in his critique of images; if, for Levinas, human suffering and the causing of human suffering is inexcusable, then images that might convey this - or simply the vulnerability of others - as a universal message should not be so readily dismissed as being outside of ethics. If we adopt the Aristotle/Gadamer approach then we lose nothing of value from Levinas' account and begin to gain a more useful conception of the image for ethical thinking. 


\subsection{The Sublime}

By returning the gesture to the image we can say that the environment that we share with other users is one that keeps us in contact with the reality of moral life. However, the second part of Levinas' dismissal of images from the moral realm remains in place: that they are totalising or, in other words, that they neutralise otherness. Now, Gadamer, when he claims that art allows for an encounter with the undecipherable, is alluding to the notion of the sublime. In closing this section I will explore the idea that the other evokes a feeling akin to that of the sublime and that images that can gesture towards that teach us about our relationship to the infinite and so our own responsibilities towards other people.

Kant defines the sublime as "a representation of limitlessness" (2008, p. 75), which is to say that, unlike the beautiful, which is about quality, the sublime is about quantity. "Sublime is the name given to what is absolutely great"; absolutely great here means great beyond all comprehension, "a greatness comparable to itself alone" (Kant 2008, p. 78). Chaos, disorder and desolation, in so far as their magnitude and power is sufficient, excite the idea of the sublime, which "contravene[s] the ends of our power of judgement" and "do[es] violence, as it were, to the imagination" (Kant 2008, p. 76). That is, the absolutely great cannot be contained in thought and so any attempt to bear it in mind is painful; or: "This excess for the imagination [...] is like an abyss in which it fears to lose itself" (Kant 2008, p. 88). We can have no control over the might of the sublime object through our minds; the sublime resists "the interest of the senses" (Kant 2008, p. 97). Whilst this sublime cannot be presented adequately to the mind, that very inadequacy is brought to mind, and so the sublime repels with its violence but also attracts with its capacity to show to the individual the mind's limits: "a negative pleasure" (Kant 2008, p. 76), both pleasure and displeasure at once. It is important to note that whilst 
something like beauty exists in the world - that is, there are things that are beautiful - the sublime is found only in our ideas.

This much is well known. Kant goes on to argue, intriguingly, that whatever it is that evokes the sublime feeling inspires respect whilst "humility [...] is a sublime temper of the mind" (2008, p. 94). Since the sublime cannot present itself to the senses there can be no comprehension, only respect and humility: "the sublime [prepares us] to esteem something highly even in opposition to our (sensuous) interest" (Kant 2008, p. 98). Without this the sublime would be merely terrifying. Not that we get any commands as to how we ought to judge when faced with the sublime; there are no rules for judging nor is there any telos or end that can be ascertained and worked towards. Since the sublime feeling is the "thrusting aside of the sensible barriers" we have only a "presentation of the infinite" (Kant 2008, p. 104). In the face of this infinite the only good that can come of it is enthusiasm - the attempt to bear witness to this unpresentable - which Kant classifies as a sublime state of mind (2008, p. 102). In this way, through humility and enthusiasm, reason can go beyond itself and into the infinite.

Utilising these ideas - the sublime, humility, enthusiasm - within the genre of ethical theory will allow us to explain morality through images. What I want to suggest is that the Levinasian other evokes a feeling akin to the sublime when encountered by the "I". Levinas' other is fundamentally unknowable. We cannot comprehend the other as other because comprehension would involve the ability to take possession of in thought - and otherness so taken possession of can no longer be other. The encounter brings us face-to-face with an abyss of otherness that resists the mind's attempts to contain it, thus showing the limitation of the capacity of thought. We are forced beyond totality and into infinity. Levinas writes: "In the idea of the Infinite, thought thinks more than it can contain" (2008a, p. 117). This would be a very fine definition 
of the sublime feeling. Bearing in mind that the sublime feeling exists in ideas and not in nature, I propose the following: just as a painting of a vast mountain range evokes the sublime feeling felt by the sheer magnitude of that range in nature, so too does the image of the other evoke the idea of the infinite experienced in the face-to-face encounter. The problem with Gadamer's account was that it offered a sort of universal responsibility that does not tally with Levinas' ethics. It was too totalising in its approach to responsibility, which would treat all others as a homogenised same. Now, though, if we combine the idea of the image as gesturing, of teaching us about the world, with the sublime, we can say that where images depict other people they remind us of the singularity of the other, the way the other escapes totality: the infinite. The image of another person reminds us of how, in the encounter, thought is forced to think more than it can contain, that something escapes it. It reminds the viewer that that which escapes thought - the other - is beyond her, that she cannot act with unlimited freedom lest it harm others. This, we might say, is a sort of moral humility. An image of another person, including avatars, is a gesture towards the responsibility we have not to act as if alone in the world. The avatars of other users are not necessarily interacted with online in a robust way and so this account of gesture and otherness through image allows us to conceive of online environments as moral even when it is a matter of shared occupation only.

However, this kind of gesture - a morality lesson without prescription - is not the same as the ethical gesture of taking responsibility for the other; being reminded of the encounter with the other through an image is not the same as the actual encounter. In the encounter, we are forced to think through our response to the other without rules or guidance (because every other is absolutely other and so no rules could pertain universally), to judge (i.e. to make moral decisions) without criteria of judgement - what we might call moral enthusiasm. As such, we need to be able to justify the claim that two users are in fact in an encounter with each other. 


\section{Sign}

With this account of moral humility through images we have taken a first step towards giving avatar interaction the nature of an ethical encounter; by conceptualising the online environment as one in which images gesture towards responsibility we have unlocked the door - but we cannot yet walk through it. If we understood online interaction purely in the terms outlined above then it would still be with what Žižek called interface simulacra; ethically significant, yes, but disconnected from the other person herself. In what follows, I will explore the viability of grounding the encounter through forms of signification, dismissing both the index and the icon but taking from these wrong-turns guidance towards what I think is the most satisfactory solution to our problem: the avatar as tensor.

\subsection{Index}

Ken Hillis, in his Online a Lot of the Time (2009), deploys a Peircian notion of index in order to explain the relation of the avatar to the user. It is worth returning to the work of Charles Sanders Peirce on the trichotomy of signs in order to see why this does not work. For Peirce (1955, pp. 99-100) a sign is that which stands in for something (an object) for someone (the person the sign addresses). This sign then creates in the mind of that person another sign: an idea. This idea is an interpretation of the sign and stands in for the object in the same way as the sign does. Crucially, a sign, for Peirce, can only represent the object; the sign cannot give the person recognition of that object. 
This broad definition of sign is then split into three kinds: icons, indices, and symbols. In Peirce's words: “An Icon is a sign which refers to the Object that it denotes merely by virtue of characters of its own" (1955, p. 102), which is to say that an icon is a substitute that represents its object by similarity or mimicry but the object need not actually exist. "An Index is a sign which refers to the Object that it denotes by virtue of being really affected by that Object" (Peirce 1955, p. 102); an index has qualities in common with the object such that it refers back to it. Indices do not have a significant resemblance to their object but they direct attention to the object itself. An index has a "dynamical (including spatial) connection both with the individual object, on the one hand, and with the senses or memory of the person for whom it serves as a sign, on the other hand" (Peirce 1955, p. 107). An index would lose all meaning if its object ceased to exist - but not if there was no-one present to interpret it. Finally: "A Symbol is a sign which refers to the Object that it denotes by virtue of a law, usually an association of general ideas, which operates to cause the Symbol to be interpreted as referring to that Object" (Peirce 1955, p. 102). A symbol would cease to have meaning if there was noone present to interpret it.

Discounting symbols, since they pertain to laws, we might suggest that the avatar is either an icon or an index, that is, that it either refers to the user by resembling the user or that it points back to the user by virtue of being somehow connected to the user. Peirce's elaboration on these two signs in particular should highlight the distinction:

The Icon has no dynamical connection with the object it represents; it simply happens that its qualities resemble those of that object, and excite analogous sensations in the mind for which it is a likeness. But it really stands unconnected with them. The Index is physically connected with its object; they make an 
organic pair, but the interpreting mind has nothing to do with the connection, except remarking it, after it is established (Peirce 1955, p. 114).

We can see then that the avatar cannot be classified as an icon (in the Peircean sense) if we wish to hold that encounters with avatars are also encounters with their users. There is no connection between icon and object - avatar and user - if we adopt the avatar-as-icon: there is only resemblance. This is further unsatisfactory since not all avatars resemble their users. The inability to ground one-to-one encounters through the icon is presumably why Hillis (2009, pp. 105-109) ignores them and adopts the index as the sign of the user online. The avatar-as-index would point back to the user, like a sign-post, fulfilling our desire for the presence of whomever we communicate with online (Hillis 2009, p. 109). Peirce noted that photographs were not mere resemblances - icons - but rather indices; this was precisely Susan Sontag's (2008, p. 9) point when she claimed that a photograph, by presenting the absence of the photographed, pointed to their presence elsewhere. Yet it is far from clear that the notion of index in the avatar context really does give us a "metaphysics of presence", as Hillis (2009, p. 109) puts it. The very fact that there needs to be a sign demonstrates that the user is not herself encountered. What we would get from the index understanding of the avatar is merely a sign-post that points us in the direction of an encounter that is yet to come. Jean-François Lyotard's critique of Peirce's notion of the sign, in his Libidinal Economy (2004), is telling in the avatar context. If we follow semioticians such as Peirce, writes Lyotard, then we get the following situation: "signification itself is constituted by signs alone $[. .$.$] it comes on endlessly [...] we never have anything but$ references [...] signification is always deferred, meaning is never present in flesh and blood" (2004, p. 43). Lyotard laments: "See what you have done: the material is immediately annihilated" (2004, p. 43). Peirce's trichotomy of signs is a "semiotic nihilism" or the "despair of lost-postponed meaning" (2004, pp. 45-46) in that meaning is always deferred in an endless 
series of signs - giving us the sort of nihilism, the deferral of the worldly, that Friedrich Nietzsche persistently railed against. If we apply Peircean indices to avatars then someone is replaced by something and the meaningful encounter with that someone needs must be deferred.

\subsection{Icon}

If index is unsatisfactory for grounding the encounter through avatars then perhaps returning to a different conception of icon might point us in the right direction. In his discussion of avatars, Falk Heinrich draws comparisons with the Byzantine icon (hereafter just "icon") in order to demonstrate that our troubles pinning down the relation between avatar and user stem from a "Western semiotic divide between representational fiction and material reality proper" (2010, p. 4). He motivates this comparison by arguing that the digital image used as an avar in, for example, social networking has shifted from having a "reflective" function to a "performative" function (2010, p. 4). That is to say, that we may no longer be able to hold, with such images, a distinction between depicted and depiction.

Icons were depictions of holy characters - such as saints, Christ, the Virgin Mary - that worked both as representation and presentation. For the believer, displaying veneration towards the icon was at the same time to venerate the religious character depicted, such that the icon was both image and materialisation of that figure. The image then is held to be real, such that the distinction between the icon and the saint is collapsed. This relationship was then excluded from the Western viewpoint as Renaissance conceptions of art - with a division between reality and media - took hold. Heinrich (2010, p. 6) explains that with the icon the depicted emerges from the picture and into the material realm of the faithful viewer, projected outwards into their 
material space. This, he contends, is one way in which we might understand the avatar. The user would emerge into the online environment and interact with the other user's avatar; and, the reverse, the other user would emerge into that environment and interact with the user's avatar. However, as Heinrich (2010, p. 8) perceptively points out, this means the interaction is not between two users but between the user and the other avatar and the other user and the user's avatar. This is problematic for a notion of ethical encounters between users online. Heinrich concludes that we are forced to believe that the other avatar is really the other user, just as the worshipper must believe that the icon is really the saint. There is a certain amount of faith, he argues, in the reliability of data transmissions through the Internet.

This is unsatisfactory, and not purely, I hope, because of Western bias or scepticism towards faith: an ethical encounter online, for it to operate in the same way that it does for Levinas offline, would have to take place between two users. Whilst this can be mediated by an environment of images, as I have argued above, there must also be an argument for that avatar being experienced as the other user herself for there to be an encounter. We need more than to blindly believe that we are encountering the other. That said, what is useful in Heinrich's account is the reversal of Hillis' position: instead of the avatar pointing back to the user, the user would here emerge forwards through their avatar; that is, we need to conceive of the avatar-sign in a way that does not demand a division between representation and reality. This might be more conducive to grounding the encounter through avatar interaction.

\subsection{Tensor}

If the problem with indices is that they point back, and with the Byzantine icon that it demands faith, what is required is a way of conceptualising the avatar as an extension forwards from the 
user into a social realm. What is required is a notion of sign that captures the extension of the body itself, and this is to be found in Lyotard's idea of the tensor. Lyotard defines the tensor as follows: "At the same time a sign which produces meaning through difference and opposition, and a sign producing intensity through force and singularity" (2004, p. 52). This requires some unpacking. As Lyotard defines it, the tensor is two things at once: intensity and tension. First, the tensor is the extension of the body beyond its organic limitation, projected outwards so that it can mingle with other bodies (Lyotard 2004, p. 58). It signifies what Lyotard calls the "intensity" of the body, what we might prefer to call "desire" or "drive" or "intention", the representation of otherwise interior propulsions. We can say on the first count that the tensor signifies the desires of its author extended beyond the limitations of her corporeality. Second, the tensor signifies the meeting point of bodies so extended, the head-on collision of different and opposing desires (Williams 1998, p. 95). So, it is both the extension of intensity and the point of tension where opposing intensities meet. This takes us beyond the kind of Peircian signs that mark the absence of that which they signify, where the encounter with the signified is always in abeyance, deferred by the dead signs that signify it. What we get instead is an encounter between two bodies, extended beyond themselves by the tensor. They meet in the middle as opposing drives. What is useful about the tensor as the meeting-point of these extended bodies is that it demands some negotiation between desires where there is conflict, the tension of the tensor (Woodward 2011, p. 224). In this way the tensor-sign should be read as an ethico-political sign, a site of conflicting interests that requires resolution but - and this is crucial and should be familiar to readers of Lyotard - it must be a resolution that does not allow for one intensity to be overwhelmed by another, what Lyotard (2007) has called elsewhere "bearing witness to the differend". 
What I want to suggest, then, is that the avatar is a tensor. What it signifies is the meeting point of two users extended beyond their bodies. This extension should be understood as the intensity of the individual, in Lyotard's idiom, or what we would more commonly think of as her desires or intentions. To encounter an avatar is to encounter a sign that stands for the inner-space of the user, perceived from the outside as action, language, and reputation. This, I believe, is the value of Lyotard's work here: noting that signs as traditionally conceived represent the deferral of the signified he argues instead, with the tensor, that we should see the sign as an outward projection of the signified such that instead of absence we get presence, referral rather deferral, liveliness rather than a dead marker. Heinrich also attempted this with his idea of the icon but that was not without its obvious flaws and it seems more prudent to reconceptualise the sign as Lyotard does than to return to a Byzantine concept. By changing the way we think about signs we open up the space for a more productive way of thinking about the avatar, one that gives it its dues as a continuation of self.

The tensor is not just that extension of the body but also the meeting place of extended bodies; not just extended intensity but tension between intensities. This, crucially, when applied to avatars, takes us away from the limitations of the "pointing back" of Hillis" account and the "pointing forwards plus faith" of Heinrich's. Not only is an avatar a tensor, and so an extension of its user, but the encounter with the avatar is a tensor, a head-on collision with that extension. Two users meet at a point of confrontation, a fundamental collision of two different people's desires. This demands negotiation, the extended intentions, the intensity of the other user palpably felt by the opposing user; in this negotiation, this social commerce, a user not only encounters the other user's avatar but the other user's will, her intensity. So an avatar is a sign that there is an other (not mere belief that there is an other) and it is the avatar as focal point that is the frontier for encountering and interacting with that other. Again, Lyotard's conception 
of the sign recommends itself because it signifies interaction between bodies rather than the passive interpretation of the sign that necessitates deferral of the signified. In this way, when applied to avatars, we get an encounter between users and not the encounter of one user (the "I") with a disconnected interface simulacrum; we get the presence of the other, and not the simulacrum as a reminder of her absence.

The final triumph of the tensor is that it makes the encounter active and not passive, demanding interaction and negotiation. If we think of the avatar in these terms then we can say that avatar interaction is an ethical encounter. Lyotard's account of how this negotiation between opposed desires in confrontation is to proceed is different to a Levinasian account. For Lyotard, the trick is not to resolve the conflict in one party's favour but to find ways to creatively reformulate the problem such that neither side must accede to the other's terms; that is, Lyotard desires dissensus and not consensus, bearing witness to the differend rather than settling the dispute. This is clearly different from Levinas' account of the encounter with another person as a confrontation. For Levinas, resolution is simple: the other goes before me, the individual responds to the needs of the other rather than to her own desires. I do not think there is a problem here: first, Lyotard's goal is primarily political rather than ethical such that he is concerned with difference groups not acquiescing to the demands of imperialist forces rather than individuals acting selflessly to prevent or alleviate the suffering of others; second, the idea of the tensor as a meeting point of two intensities does not demand Lyotard's solution to the tension, such that it is perfectly consistent to reject his and adopt another if deemed desirable. This is not the place to discuss the efficacy of Lyotard's political project so suffice it to say that since the present concern is with ethics it is, at the very least, consistent to seek to explain tension in ethical terms where it is ethical in nature (i.e. when the tension is between responding to the other or pursuing one's own projects). And, in those terms, we can say that the encounter 
with the other person through their avatar is a point at which there is a tension of opposing intensities; this confrontation is experienced as a limitation of my freedom to act without consideration of how this might run counter to the desires and goals of the other person. The tensor as the meeting point of two extended bodies is a sign that consummates my responsibility for the other person. More than this, where there is an encounter with an avatar that calls for help or that expresses the suffering of its user that responsibility becomes a demand for response, a moral enthusiasm.

In short: if the avatar is a tensor then it extends the user forwards such that they can be encountered; since the meeting of two users so extended is also a tensor, it is a sign that intentions and desires must be limited, that responsibility must be taken not to do harm to the intensity of the other (moral humility); and where the encounter with the other (grounded in the tensor) brings suffering to attention, that responsibility needs must become a response to alleviate said suffering (moral enthusiasm). That is, avatar interaction has the nature of an ethical encounter.

\section{Concluding Remarks}

As new media become more and more integral to the ways we interact with people, avatars come to the fore. Whether through social networking sites or webcams or graphic virtual worlds the image gains greater importance for how we encounter other people. The images that constitute virtual environments should be understood as morally evocative, as gesturing towards the concrete reality they represent. By bringing to the mind the sublime otherness of the other person they are at the same time a moral lesson: they remind us that the other person 
ought to be beyond our unfettered desires, that we must limit our own actions so as not to do injustice to them. Further, images of suffering are gestures towards the brute fact that the suffering of others is inexcusable. These, though, are general lessons, built into the environment itself. Unless the avatar can be understood as an extension of a specific person then all we get is a sense of general responsibility rather than a responsibility directed towards a particular other. The avatar must also signify the other person it stands in for; avatars need to be understood as kinds of signs of specific other people. So, I have further argued that the user is extended forward by the avatar such that she can be encountered despite the fact that she is not physically present. The avatar-as-tensor is a sign that demands contemplation about how one's actions may infringe upon the intentions of the person it represents, and therefore it stands as a limitation to one's freedom. With this work on images and signs complete we can then return to a Levinasian notion of responsibility: such limitation is responsibility for the person that avatar represents; one's actions should not harm that other person (what I have called moral humility) and, where suffering is expressed, they should be directed towards responding appropriately (what I have called moral enthusiasm). By arguing for the moral evocation of images and for the extension of the user through the avatar, the avatar-as-tensor, I have attempted to show that, contra Žižek, interaction between users is possible in online environments and that the ethical encounter can be motivated through avatars. In sum, if we go beyond both Levinas' account of the image and traditional understandings of the sign, then we can go beyond the avatar - and towards the other person that it stands in for.

\section{Acknowledgements}


I would like to thank Nick Gane, Dave Beer, James Williams, and Dave Boothroyd for helpful comments on earlier drafts. My thanks must also go to the anonymous reviewers for providing illuminating readings of the original submission.

\section{References}

Aristotle (1997) Poetics, trans. S. H. Butcher, Dover, New York.

Bauman, Z. (2007) Modernity and the Holocaust, Polity, Cambridge.

Boothroyd, D. (2005) “"To be Hospitable to Madness": Derrida and Foucault Chez Freud', Journal for Cultural Research, vol. 9, no. 1, pp. 3-21.

Caygill, H. (2006) 'Bearing Witness to the Infinite: Nancy and Levinas', Journal for Cultural Research, vol. 9, no. 4, pp. 351-357.

Dawes, S. (2011) 'The Role of the Intellectual in Liquid Modernity: An Interview with Zygmunt Bauman', Theory, Culture \& Society, vol. 28, no. 3, pp. 130-148.

Falvey, L. D. (2011) 'Reconstructing Power in Second Life®: Controlling the Virtual Mayhem', Journal for Cultural Research, vol. 15, no. 1, pp. 55-74.

Gadamer, H.-G. (1986a) 'Art and Imitation', in R. Bernasconi (ed), The Relevance of the Beautiful and Other Essays, Cambridge University Press, Cambridge, pp. 92-104. 
Gadamer, H.-G. (1986b) 'Image and Gesture', in R. Bernasconi (ed), The Relevance of the Beautiful and Other Essays, Cambridge University Press, Cambridge, pp. 74-82.

Gadamer, H.-G. (1986c) 'The Speechless Image', in R. Bernasconi (ed), The Relevance of the Beautiful and Other Essays, Cambridge University Press, Cambridge, pp. 83-91.

Gunkel, D. J. (2010) 'The Real Problem: Avatars, Metaphysics and Online Social Interaction', New Media \& Society, vol. 12, no. 1, pp. 127-141.

Heinrich, F. (2010) 'On the Belief in Avatars: What on Earth have the Aesthetics of the Byzantine Icons to do with the Avatar in Social Technologies?', Digital Creativity, vol. 21, no. 1, pp. 4-10.

Hell, J. (2010) 'Modernity and the Holocaust, or, Listening to Eurydice', Theory, Culture \& Society, vol. 27, no. 6, pp. 125-154.

Hillis, K. (2009) Online a Lot of the Time: Ritual, Fetish, Sign, Duke University Press, London.

Kant, I. (2008) Critique of Judgement, trans. J. C. Meredith, Oxford University Press, Oxford.

Klang, M. (2004) 'Avatar: From Deity to Corporate Property: A Philosophical Inquiry into Digital Property in Online Games', Information, Communication \& Society, vol. 7, no. 3, pp. $389-402$. 
Levinas, E. (2006a) Humanism of the Other, trans. N. Poller, University of Illinois Press, Chicago.

Levinas, E. (2006b) 'Reality and its Shadow', in Collected Philosophical Papers, trans. A. Lingis, Duquesne University Press, Pittsburgh, pp. 1-13.

Levinas, E. (2007) Totality and Infinity: An Essay on Exteriority, trans. A. Lingis, Duquesne University Press, Pittsburgh.

Levinas, E. (2008a) 'Diachrony and Representation', in Time and the Other and Additional Essays, trans. R. A. Cohen, Duquesne University Press, Pittsburgh, pp. 97-120.

Levinas, E. (2008b) Otherwise Than Being, or, Beyond Essence, trans. A Lingis, Duquesne University Press, Pittsburgh.

Lyotard, J.-F. (2004) Libidinal Economy, trans. I. H. Grant, Continuum, London.

Lyotard, J.-F. (2007) The Differend: Phrases in Dispute, trans. G. Van Den Abbeele, University of Minnesota Press, Minneapolis.

Peirce, C. S. (1955) 'Logic as Semiotic: The Theory of Signs’, in J. Buchler (ed), Philosophical Writings of Peirce, Dover, New York, pp. 98-119.

Plato (1997) 'Republic', in J. M. Cooper (ed), Complete Works, Hackett, Cambridge, pp. 9711223. 
Robbins, J. (1999) Altered Reading: Levinas and Literature, The University of Chicago Press, London.

Sontag, S. (2008) On Photography, Penguin, London.

Stephenson, N. (2002) Snow Crash, Penguin, London.

Webb, S. (2001) 'Avatar Culture: Narrative, Power and Identity in Virtual World Environments', Information, Communication \& Society, vol. 4, no. 4, pp. 560-594.

Williams, J. (1998) Lyotard: Towards a Postmodern Philosophy, Polity, Cambridge.

Woodward, A. (2011) 'Tensor', in S. Sim (ed), The Lyotard Dictionary, Edinburgh University Press, Edinburgh, pp. 222-224.

Žižek, S. (1999) 'Is it Possible to Traverse the Fantasy in Cyberspace?', in E. Wright \& E. Wright (eds), The Žižek Reader, Blackwell, Oxford, pp. 102-124. 